\title{
Biosensors of Laccase Based on Hydrophobic Ionic Liquids Derived from Imidazolium Cation
}

\author{
Ana Cristina Franzoi, ${ }^{*}, a$ Iolanda Cruz Vieira ${ }^{a}$ and Jairton Dupont ${ }^{b}$ \\ ${ }^{a}$ Departamento de Química, Laboratório de Biossensores, Universidade Federal de Santa Catarina, \\ 88040-970 Florianópolis-SC, Brazil \\ ${ }^{b}$ Departamento de Química Orgânica, Laboratório de Catálise Molecular, Universidade Federal do \\ Rio Grande do Sul, 91501-970 Porto Alegre-RS, Brazil
}

\begin{abstract}
Biossensores contendo lacase (Aspergillus oryzae) e líquidos iônicos derivados do cátion 1-butil-3-metilimidazol (BMI) associados com os ânions hexafluorfosfato $\left(\mathrm{BMI} \cdot \mathrm{PF}_{6}\right)$ ou bis(trifluormetilsulfonil)imida $\left(\mathrm{BMI} \cdot \mathrm{Tf}_{2} \mathrm{~N}\right)$ foram construídos para determinação de adrenalina. $\mathrm{O}$ biossensor baseado no $\mathrm{BMI} \cdot \mathrm{Tf}_{2} \mathrm{~N}$ foi selecionado por apresentar maior resposta quando comparado ao $\mathrm{BMI} \cdot \mathrm{PF}_{6}$. As melhores condições para otimização foram estabelecidas por voltametria de onda quadrada (amplitude $100 \mathrm{mV}$, frequência $10 \mathrm{~Hz}$ e incremento 4,0 mV). O melhor desempenho foi obtido em 50:20:15:15\% (m/m/m/m) de pó de grafite:lacase:Nujol:LIs em tampão acetato $0,1 \mathrm{~mol} \mathrm{~L}^{-1}$ (pH 4,0). A curva analítica foi linear na faixa de concentração $2,49 \times 10^{-6}$ a $2,27 \times 10^{-4} \mathrm{~mol} \mathrm{~L}^{-1}$ com limite de detecção de $5,34 \times 10^{-7} \mathrm{~mol} \mathrm{~L}^{-1}$. A recuperação de adrenalina em amostras injetáveis variou de 96,3 a $101,6 \%$. Os resultados obtidos para a adrenalina usando o biossensor proposto e o procedimento da Farmacopéia Americana estão em concordância ao nível de confiança de $95 \%$.
\end{abstract}

Biosensors based on laccase from Aspergillus oryzae and ionic liquids derived from the 1-butyl3-methylimidazolium cation (BMI) associated with the anions hexafluorophosphate $\left(\mathrm{BMI} \cdot \mathrm{PF}_{6}\right)$ or bis(trifluoromethylsulfonyl)imide $\left(\mathrm{BMI} \cdot \mathrm{Tf}_{2} \mathrm{~N}\right)$ were constructed for adrenaline determination. The biosensor based on $\mathrm{BMI} \cdot \mathrm{Tf}_{2} \mathrm{~N}$ was selected by presenting higher response when compared with that based on $\mathrm{BMI} \cdot \mathrm{PF}_{6}$. The best conditions for the optimization were established by square wave voltammetry (pulse amplitude $100 \mathrm{mV}$, frequency $10 \mathrm{~Hz}$ and scan increment $4.0 \mathrm{mV}$ ). The best performance was obtained with 50:20:15:15\% (m/m/m/m) as the graphite powder:laccase:Nujol:ILs composition in $0.1 \mathrm{~mol} \mathrm{~L}^{-1}$ acetate buffer solution $(\mathrm{pH} 4.0)$. The analytical curve was linear in the concentration range $2.49 \times 10^{-6}$ to $2.27 \times 10^{-4} \mathrm{~mol} \mathrm{~L}^{-1}$ with a detection limit of $5.34 \times 10^{-7} \mathrm{~mol} \mathrm{~L}^{-1}$. The recovery of adrenaline in injectable samples ranged from 96.3 to $101.6 \%$. The results obtained for the adrenaline using the proposed biosensor and the United States Pharmacopeia procedure were in agreement at the $95 \%$ confidence level.

Keywords: biosensor, laccase, ionic liquids, imidazolium, bis(trifluoromethylsulfonyl)imide, adrenaline

\section{Introduction}

Epinephrine, often called adrenaline, a hormone secreted from the adrenal glands, is an important catecholamine for message transfer in mammalian central nervous systems, present in nerve tissue and body fluids in the form of large organic cations. Studies show that many diseases are related to changes in its concentration. The quantitative determination of adrenaline is of great help in understanding the effects of the nervous system and

*e-mail: aninhafranzoi@yahoo.com.br artificial substitutes, and is of great significance to research in the areas of pharmacology and the life sciences. ${ }^{1,2}$

A number of methods have been applied in adrenaline determination including spectrophotometry, ${ }^{3}$ fluorimetry, ${ }^{4}$ liquid chromatography coupled with various detection techniques, ${ }^{5}$ capillary electrophoresis, ${ }^{6}$ chemiluminescence ${ }^{7}$ and electrochemiluminescence. ${ }^{8}$ Adrenaline is an electroactive molecule and it is important to examine its electrochemical behavior, thus electrochemical detection with various modified electrodes has also been reported. ${ }^{1,2,9-13}$ Brondani et al. ${ }^{9}$ have investigated the detection of adrenaline with a biosensor containing the ionic 
liquid 1-butyl-3-methylimidazolium hexafluorophosphate $\left(\mathrm{BMI} \cdot \mathrm{PF}_{6}\right)$ and a corn (Zea Mays L.) homogenate as a source of peroxidase immobilized in chitin chemically crosslinked with carbodiimide and glyoxal. The amperometric response of adrenaline was carried out at $-0.23 \mathrm{~V}(\mathrm{vs} . \mathrm{Ag} / \mathrm{AgCl})$ via the electrochemical reduction of the product of the enzymatic reaction. Felix ${ }^{13}$ have developed a biosensor to determine adrenaline in pharmaceutical samples. The polyphenol oxidase enzymes present in the fibers of palm tree fruits (Livistona chinensis) catalyze the oxidation of adrenaline to adrenaline-quinone as a primary product. This product is then electrochemically reduced on the biosensor surface and the resulting current is used for its quantification. In addition, biosensors have some advantages, such as low cost, simplicity of construction and rapid response.

Biosensors are sensors modified with biological material (enzymes, antibodies, organelles, microorganisms and animal and plant tissues) integrated to the electronic transducer that converts a biochemical signal into a quantifiable analytical response. ${ }^{14}$ One of the most important enzymes in terms of applicability and versatility in industry is laccase. This is a type of copper-containing polyphenol oxidase, one of the extracellular glycoprotein enzymes obtained from white-rot fungi and other natural sources. This enzyme acts on substrates such as polyphenols, aminophenols and methoxy-substituted phenols by catalyzing the oxidation of their phenolic hydroxyl groups to phenoxy radicals while molecular oxygen is reduced to water. ${ }^{15}$ Numerous biosensors based on laccase have been described in the literature. ${ }^{16-22}$

Ionic liquids (ILs) are organic salts, which are liquid at ambient temperature. Unlike traditional solvents, which can be described as molecular liquids, ILs are composed of ions. They possess a unique association of properties including non-volatility, non-flammability and excellent chemical and thermal stability. ${ }^{23,24}$ The class of ILs based on imidazolium cations exhibits a wider liquid range and an electrochemical window (up $7.0 \mathrm{~V}$ ) and these have therefore become ideal electrolytes in electrochemical devices like batteries, capacitors and electrochemical sensors and biosensors. ${ }^{24-29}$ Nujol and paraffin are the most commonly used binder components of carbon electrode pastes. Recently, these traditionally used binders have been totally or partially replaced with ILs, indicating that they offer an attractive and efficient alternative, due to the high ionic conductivity and sensitivity of the resulting electrodes..$^{9,10,17,18,30-36}$ There are several known hydrophobic ILs and those containing the bis(trifluoromethylsulfonyl)imide $\left(\mathrm{Tf}_{2} \mathrm{~N}^{-}\right)$anion offer several advantages for use in electrochemistry. In relation to the analogous ILs based on the $\mathrm{PF}_{6}^{-}$anion they are less viscous, water stable and have good conductivity, excellent thermal stability and a large electrochemical window. ${ }^{24}$ Therefore, these hydrophobic ILs are promising candidates for the construction of novel biosensors.

In this paper the electrochemical behavior of adrenaline was investigated on biosensors containing the enzyme laccase from Aspergillus oryzae using ILs $\left(\mathrm{BMI} \cdot \mathrm{Tf}_{2} \mathrm{~N}\right.$ or $\mathrm{BMI} \cdot \mathrm{PF}_{6}$ ) and Nujol mixtures as the binder. The biosensors were then applied to adrenaline determination. The excellent properties of ILs effectively facilitate the fast electron transfer on the biosensor surface and improve sensitivity in the determination of this catecholamine in injectable samples. The experimental conditions, such as Nujol:ILs ratio, enzyme percentage, solution $\mathrm{pH}$ and square-wave voltammetry parameters (frequency, pulse amplitude and scan increment) for the analytical performance of the biosensors were optimized. The results obtained for the adrenaline determination in injectable samples using the proposed biosensor and those obtained using the spectrophotometric method are in agreement at the $95 \%$ confidence level.

\section{Experimental}

\section{Reagents and solutions}

All reagents were of analytical grade and used without further purification. Ultrapure water $(18.2 \mathrm{M} \Omega \mathrm{cm})$ was obtained from a Milli-Q purification system and used throughout the experiments. Laccase from Aspergillus oryzae was purchased from Novozymes (Denilite ${ }^{\circledR}$ II BASE) in the form of microspheres. Graphite powder (grade \#38) and Nujol were supplied by Fisher Scientific and Aldrich, respectively. Adrenaline, carbidopa, methyldopa, levedopa, sodium chloride, sucrose, lactose, magnesium stearate, poly(ethylene glycol) and starch were purchased from Sigma. The ionic liquids 1-butyl-3methylimidazolium hexafluorophosphate $\left(\mathrm{BMI} \cdot \mathrm{PF}_{6}\right)$ and 1-butyl-3-methylimidazolium bis(trifluoromethylsulfonyl) imide $\left(\mathrm{BMI} \cdot \mathrm{Tf}_{2} \mathrm{~N}\right)$ were synthesized as previously described in the literature. ${ }^{37,38} 0.1 \mathrm{~mol} \mathrm{~L}^{-1}$ Acetate buffer solution ( $\mathrm{pH} 4.0$ ) was used as the supporting electrolyte. Injectable samples containing adrenaline were acquired from the University Hospital in Florianópolis (Santa Catarina, Brazil) and analyzed using the proposed biosensor and a standard spectrophotometric method.

\section{Biosensor construction}

To prepare $200.0 \mathrm{mg}$ of paste, initially $40.0 \mathrm{mg}$ ( $20 \%$, $\mathrm{m} / \mathrm{m})$ of laccase and $100.0 \mathrm{mg}(50 \%, \mathrm{~m} / \mathrm{m})$ of graphite 
powder were hand mixed in a mortar for $10 \mathrm{~min}$ to ensure uniform dispersion. After this, $30.0 \mathrm{mg}$ of Nujol (15\%, $\mathrm{m} / \mathrm{m})$ and $30.0 \mathrm{mg}$ of $\mathrm{BMI} \cdot \mathrm{PF}_{6}$ or BMI $\cdot \mathrm{Tf}_{2} \mathrm{~N}(15 \%, \mathrm{~m} / \mathrm{m})$ were added to this mixture which was mixed for at least 20 min to produce the final paste. A portion of the resulting paste was packed firmly into the cavity of a $1.0 \mathrm{~mL}$ plastic syringe and a copper wire was inserted, on the opposite side, to obtain the external electrical contact. The biosensors were stored at room temperature when not in use. For comparison, the carbon paste electrode (CPE) without laccase was prepared following the same steps.

\section{Electrochemical and spectrophotometric measurements}

Electrochemical measurements, using square-wave voltammetry, were performed on an Autolab PGSTAT12 potentiostat/galvanostat (Eco Chemie Utrecht The Netherlands) connected to data processing software (GPES, version 4.9.006, Eco Chemie). The electrochemical cell was assembled with a conventional three-electrode system: biosensors based on the different ILs BMI-Tf ${ }_{2} \mathrm{~N}$-laccase and $\mathrm{BMI} \cdot \mathrm{PF}_{6}$-laccase as the working electrodes (surface area $0.8 \mathrm{~mm}^{2}$ ), a platinum wire as the auxiliary electrode and an $\mathrm{Ag} / \mathrm{AgCl}\left(3.0 \mathrm{~mol} \mathrm{~L}^{-1} \mathrm{KCl}\right)$ as the reference electrode. Voltammetric measurements were carried out in an unstirred, non de-aerated acetate buffer solution (pH 4.0) at $25.0 \pm 0.5^{\circ} \mathrm{C}$ and all potentials were measured and reported vs. $\mathrm{Ag} / \mathrm{AgCl}$. In a typical run, $10 \mathrm{~mL}$ of the acetate buffer solution was transferred to a clean, dry cell and the required volume of the adrenaline or injectable sample was added by micropipette. After a stirring period of $60 \mathrm{~s}$ to homogenize the solution, square-wave voltammograms were recorded.

To compare the results obtained by the methodology here proposed, we followed the UV spectrophotometric method established in the United States Pharmacopoeia. ${ }^{39}$ A Hewlett-Packard (Boise, ID, USA) UV-Visible spectrophotometer, model $8452 \mathrm{~A}$, with a quartz cell (optical path of $1.00 \mathrm{~cm}$ ) was used as the standard method for the adrenaline determination.

\section{Determination of Michaelis-Menten constant}

The Michaelis-Menten kinetic constant $\left(\mathrm{K}_{m}^{a p p}\right)$ was determined using the Lineweaver-Burk equation and employing the proposed biosensor in the concentration range of $2.49 \times 10^{-6}$ to $5.18 \times 10^{-4} \mathrm{~mol} \mathrm{~L}^{-1}$ adrenaline in $0.1 \mathrm{~mol} \mathrm{~L}^{-1}$ acetate buffer solution ( $\mathrm{pH} 4.0$ ) at $25.0 \pm 0.5^{\circ} \mathrm{C}$. The current response was measured by square-wave voltammetry at a frequency of $10 \mathrm{~Hz}$, pulse amplitude of $100 \mathrm{mV}$ and scan increment of $4.0 \mathrm{mV}$.

\section{Results and Discussion}

Biosensors based on imidazolium ILs: voltammetric response to adrenaline

ILs are generally divided into two groups according to their solubility in water. The first type, water-miscible (hydrophilic) ILs, such as $\mathrm{BMI} \cdot \mathrm{BF}_{4}$ have received less attention, because they have so far been considered unstable in aqueous solution. However, the second type, waterimmiscible (hydrophobic) ILs, such as those based on $\mathrm{PF}_{6}{ }^{-}$and $\mathrm{Tf}_{2} \mathrm{~N}^{-}$anions have proved to be promising for the construction the biosensors due to their hydrophobic nature, forming non-polarizable interfaces when in contact with water. ${ }^{24}$ The imidazolium-based IL molecular structures are shown in Figure 1. In addition, the enzyme laccase is a multicopper oxidase which catalyze the four-electron reduction of molecular oxygen to water and the oxidation of a variety of aromatic compounds. ${ }^{15}$ Laccase immobilized on the biosensor catalyzes the oxidation of adrenaline present in the solution to the corresponding $o$-quinone. This product is electrochemically reduced back to adrenaline on the surface of the biosensor as shown in Figure 1. The resulting reduction current is used as the analytical response for adrenaline determination.

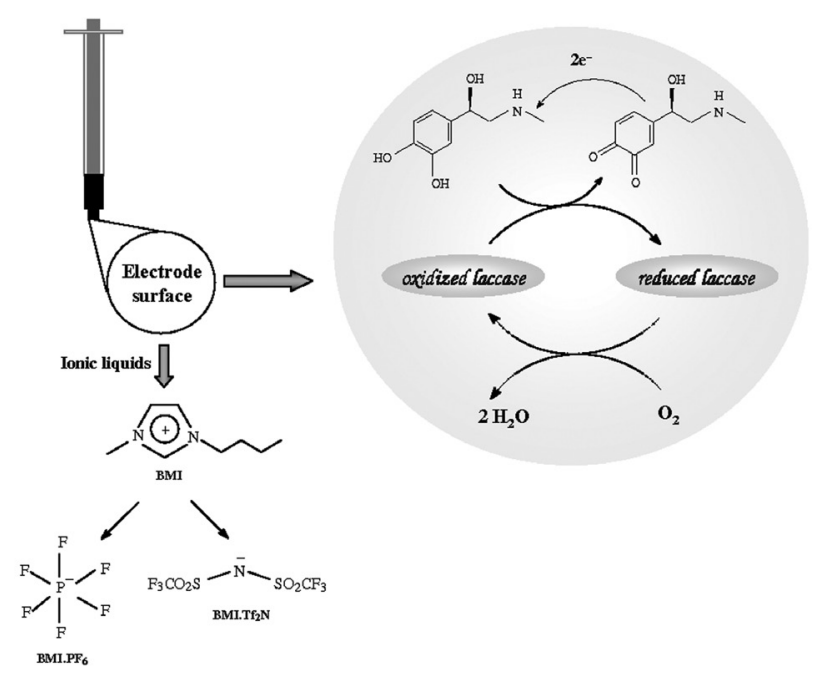

Figure 1. Enzymatic reaction involving adrenaline and laccase on biosensor surface and structure of the ILs derived from the 1-butyl3-methylimidazolium cation (BMI) associated with the anions hexafluorophosphate (BMI.PF ) or bis(trifluoromethylsulfonyl)imide $\left(\mathrm{BMI} \cdot \mathrm{Tf}_{2} \mathrm{~N}\right)$.

The square-wave voltammograms using $6.10 \times 10^{-5} \mathrm{~mol} \mathrm{~L}^{-1}$ adrenaline in $0.1 \mathrm{~mol} \mathrm{~L}^{-1}$ acetate buffer solution ( $\mathrm{pH} 4.0$ ) were recorded between +0.4 and $-0.3 \mathrm{~V}$ vs. $\mathrm{Ag} / \mathrm{AgCl}\left(\mathrm{BMI} \cdot \mathrm{PF}_{6}\right)$ and +0.4 and $-0.5 \mathrm{~V}$ vs. $\mathrm{Ag} / \mathrm{AgCl}$ $\left(\mathrm{BMI} \cdot \mathrm{Tf}_{2} \mathrm{~N}\right)$. The electrochemical behavior of adrenaline 
was investigated in the presence of the biosensors based on laccase with $\mathrm{BMI} \cdot \mathrm{PF}_{6}: \mathrm{Nujol}$ or $\mathrm{BMI} \cdot \mathrm{Tf}_{2} \mathrm{~N}$ :Nujol as binders and also, for comparison, in the presence the bare CPEs. Figure 2 shows the voltammograms obtained using (a') BMI $\cdot \mathrm{PF}_{6}-\mathrm{CPE}$, (a) $\mathrm{BMI} \cdot \mathrm{PF}_{6}$-biosensor, (b') BMI-Tf ${ }_{2} \mathrm{~N}-\mathrm{CPE}$, and (b) BMI-Tf ${ }_{2} \mathrm{~N}-$ biosensor. It can be noted that the $\mathrm{BMI} \cdot \mathrm{PF}_{6}$ - and $\mathrm{BMI} \cdot \mathrm{Tf}_{2} \mathrm{~N}$-biosensors gave higher responses when compared with $\mathrm{BMI} \cdot \mathrm{PF}_{6}-\mathrm{CPE}$ and $\mathrm{BMI} \cdot \mathrm{Tf}_{2} \mathrm{~N}-\mathrm{CPE}$, respectively. This is attributed to the presence of the laccase which catalyzes the oxidation of adrenaline to the corresponding $o$-quinone which is then electrochemically reduced back to adrenaline on the surface of the biosensor. The laccase enzyme favors the redox reaction, generating higher response for the reduction wave of $o$-quinone to adrenaline at an approach potential of $-0.12 \mathrm{~V}$ for the biosensors. The peak observed around $+0.1 \mathrm{~V}$ can be attributed to the neighboring group $\mathrm{OH}$ of the phenolic ring, however, the increase in this peak is not significant when compared with the peak at $-0.12 \mathrm{~V}$ (attributed to the reduction of $o$-quinone to regenerate the initial compound).

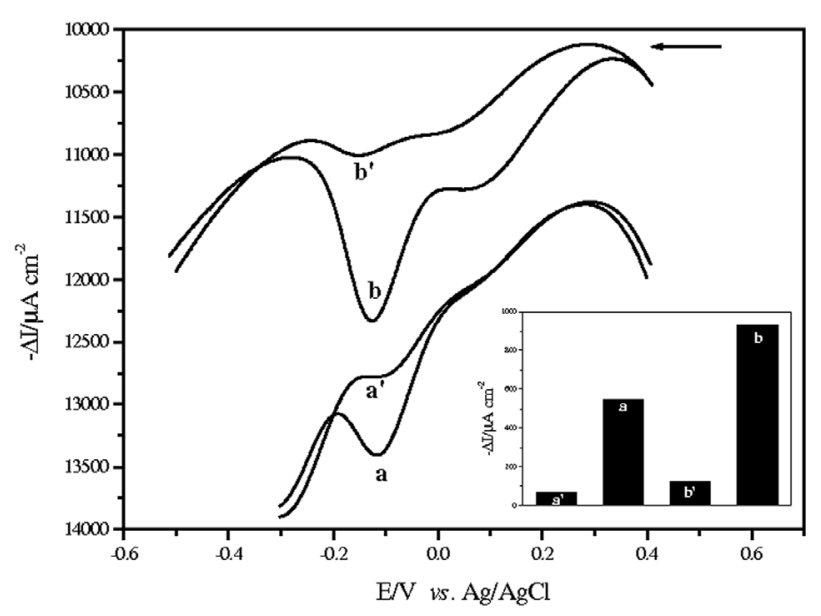

Figure 2. Square-wave voltammograms obtained using (a') BMI.PF ${ }_{6}-\mathrm{CPE}$, (a) BMI.PF ${ }_{6}$-biosensor, (b') BMI-Tf ${ }_{2} \mathrm{~N}-\mathrm{CPE}$ and (b) BMI-Tf ${ }_{2} \mathrm{~N}$-biosensor with $6.10 \times 10^{-5} \mathrm{~mol} \mathrm{~L}^{-1}$ adrenaline in $0.1 \mathrm{~mol} \mathrm{~L}^{-1}$ acetate buffer solution (pH 4.0); (a' and a) pulse amplitude $100 \mathrm{mV}$, frequency $20 \mathrm{~Hz}$ and scan increment $1.0 \mathrm{mV}$ and (b' and b) pulse amplitude $100 \mathrm{mV}$, frequency $10 \mathrm{~Hz}$ and scan increment $4.0 \mathrm{mV}$. Inset: current values for each CPE and biosensor.

In addition, the $\mathrm{BMI} \cdot \mathrm{Tf}_{2} \mathrm{~N}$ :Nujol binder mixture led to an increase in the biosensor response and a large difference in the value of the cathodic current was observed when compared with the $\mathrm{BMI} \cdot \mathrm{PF}_{6}$-biosensor. Due to hydrolysis of $\mathrm{PF}_{6}^{-}$, the imidazolium salts with $\mathrm{Tf}_{2} \mathrm{~N}^{-}$are increasingly used as hydrophobic ILs. ${ }^{24}$ Thus, the $\operatorname{Tf}_{2} \mathrm{~N}^{-}$anion is preferred as the counter ion for the $\mathrm{N}, \mathrm{N}$-dialkyl substituted imidazolium cation because it is less viscous, more stable in water, and has good electrochemical conductivity and a wide electrode potential window in aqueous solutions. ${ }^{24}$ Therefore, the $\mathrm{BMI} \cdot \mathrm{Tf}_{2} \mathrm{~N}$-biosensor was chosen for the development of this study, and also biosensors based on the laccase and ILs based on $\mathrm{BMI} \cdot \mathrm{Tf}_{2} \mathrm{~N}$ for the determination of adrenaline have not been described in the literature. Our research group has previously developed a biosensor containing laccase and ILs for the determination of phenolic compounds. ${ }^{17,18}$ As can be seen, for biosensor BMI·Tf ${ }_{2} \mathrm{~N}$-laccase, a higher response for the reduction wave of $o$-quinone reduction to rutin at a potential of $+0.31 \mathrm{~V}$ was observed when compared with DMI $\cdot \mathrm{Tf}_{2} \mathrm{~N}$-laccase and TDMI $\cdot \mathrm{Tf}_{2} \mathrm{~N}$-laccase. This behavior shows that the IL structure ( $N$-alkyl chain length) is inversely proportional to the conductivity, that

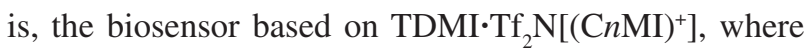
$n=14$ carbon atoms) gives the lowest response to rutin. ${ }^{17}$ The $\mathrm{BMI} \cdot \mathrm{PF}_{6}$-biosensor showed a higher response for the reduction wave of $o$-quinone to rosmarinic acid when compared with the $\mathrm{BMI} \cdot \mathrm{BF}_{4}$-biosensor. The presence of the hydrophobic IL·BMI $\cdot \mathrm{PF}_{6}$ offers a greater stability, good electrochemical conductivity and a wide electrode potential window in aqueous solutions. ${ }^{18}$ There are also three reports on the use of biosensors containing laccase and an $\mathrm{IL} \cdot \mathrm{BMI} \cdot \mathrm{PF}_{6}$ for the inhibition of laccase activity by halide ions and as catalysts of the cathode of biofuel cells. ${ }^{40-42}$

\section{Optimization of experimental parameters of the $\mathrm{BMI} \cdot \mathrm{Tf} \mathrm{N}_{2} \mathrm{~N}$ -} biosensor

Various experimental conditions for the biosensor response, such as Nujol:BMI $\cdot \mathrm{Tf}_{2} \mathrm{~N}$ ratios, percentage of laccase, $\mathrm{pH}$, and square-wave voltammetry parameters, were investigated in order to obtain the best performance. The biosensor response was based on the cathodic peak current for a $6.10 \times 10^{-5} \mathrm{~mol} \mathrm{~L}^{-1}$ adrenaline solution using square-wave voltammetry. Table 1 summarizes the range over which each parameter was investigated and the optimal values found.

Table 1. Optimization of the experimental conditions

\begin{tabular}{lcc}
\hline $\begin{array}{l}\text { Parameters } \\
\text { investigated }\end{array}$ & $\begin{array}{c}\text { Range } \\
\text { studied }\end{array}$ & $\begin{array}{c}\text { Optimal } \\
\text { value }\end{array}$ \\
\hline Nujol:BMI·Tf ${ }_{2} \mathrm{~N}(\%, \mathrm{~m} / \mathrm{m})$ & $100: 0-0: 100$ & $50: 50$ \\
Laccase $(\%, \mathrm{~m} / \mathrm{m})$ & $10-30$ & 20 \\
$\mathrm{pH}$ & $4.0-8.0$ & 4.0 \\
Frequency $(\mathrm{Hz})$ & $10-100$ & 10 \\
Pulse amplitude $(\mathrm{mV})$ & $10-100$ & 100 \\
Scan increment $(\mathrm{mV})$ & $0.5-5.0$ & 4.0 \\
\hline
\end{tabular}

The effect of Nujol:BMI $\cdot \mathrm{Tf}_{2} \mathrm{~N}$ compositions of (a) 100:0; (b) 75:25; (c) 50:50; (d) 25:75 and (e) 0:100\%, 
$(\mathrm{m} / \mathrm{m})$ on the biosensor response was investigated. It was observed that the analytical response increased with an increase in the percentage of $\mathrm{BMI} \cdot \mathrm{Tf}_{2} \mathrm{~N}$ used up to $50 \%$ and decreased at higher percentages (data not shown). Thus, the Nujol:IL ratio of $50: 50 \% \mathrm{~m} / \mathrm{m}$ was used for further construction of the biosensor. The influence of laccase in percentages from 10 to $30 \%(\mathrm{~m} / \mathrm{m})$ on the biosensor was investigated. The analytical signals (cathodic peak currents) became larger with increases in the enzyme composition up to $20 \%(\mathrm{~m} / \mathrm{m})$. Consequently, this is the most suitable amount of enzyme and it was selected for further studies. The composition of 50:20:15:15\% $(\mathrm{m} / \mathrm{m} / \mathrm{m} / \mathrm{m})$ graphite powder:laccase:Nujol:BMI.PF, respectively, was used in the construction of the BMI-Tf ${ }_{2} \mathrm{~N}$-biosensor. These results (Nujol:BMI $\cdot \mathrm{Tf}_{2} \mathrm{~N}$ ratio $50: 50 \%$ and laccase percentage of $20 \%$ ) are in agreement with that obtained using the $\mathrm{BMI} \cdot \mathrm{Tf}_{2} \mathrm{~N}-$ and $\mathrm{BMI} \cdot \mathrm{PF}_{6}$-biosensors in the rutin and rosmarinic acid determination, respectively. ${ }^{17,18}$

With respect to effect of $\mathrm{pH}(4.0-8.0)$, the current response resulting from the laccase-catalyzed reaction achieved a maximum value at $\mathrm{pH} 4.0$, decreasing at other $\mathrm{pH}$ values and this $\mathrm{pH}$ was therefore selected for further experiments. Electrochemical responses of the biosensor to adrenaline are dependent on the square-wave parameters. The effect of varying frequency (10 to $100 \mathrm{~Hz}$ ), pulse amplitude (10 to $100 \mathrm{mV}$ ) and scan increment (1.0 to $5.0 \mathrm{mV}$ ) were investigated and the best analytical signals obtained for the BMI $\cdot \mathrm{Tf}_{2} \mathrm{~N}$-biosensor were $10 \mathrm{~Hz}, 100 \mathrm{mV}$ and $4.0 \mathrm{mV}$, respectively. These experimental conditions were therefore selected for subsequent experiments.

\section{Square-wave voltammograms and analytical curve of adrenaline}

Under the optimal conditions mentioned above, the analytical curve obtained for the adrenaline was linear from $2.49 \times 10^{-6}$ to $2.27 \times 10^{-4} \mathrm{~mol} \mathrm{~L}^{-1}$ and the regression equation found was $\Delta \mathrm{I}=-8.40+9.19 \times 10^{6}$ [adrenaline] ( $\Delta \mathrm{I}: \mu \mathrm{A} \mathrm{cm} \mathrm{cm}^{-2}$; [adrenaline]: $\mathrm{mol} \mathrm{L}^{-1}$ and $\left.\mathrm{r}=0.9999\right)$. The detection limit (three times the blank signal/slope) was calculated using this calibration curve and was found to be $5.34 \times 10^{-7} \mathrm{~mol} \mathrm{~L}^{-1}$. Figure 3 shows these voltammograms, when the cathodic current density increased with adrenaline concentration, and the corresponding analytical curve can be seen in the inset.

The analytical features of the $\mathrm{BMI} \cdot \mathrm{Tf}_{2} \mathrm{~N}$-biosensor developed in this study was compared with other biosensors for adrenaline determination. ${ }^{1,2,9-13}$ Our proposed BMI.Tf ${ }_{2} \mathrm{~N}$-biosensor exhibited excellent performance in terms of wide linear range, good correlation coefficient and low limit of detection, and theses results are comparable,

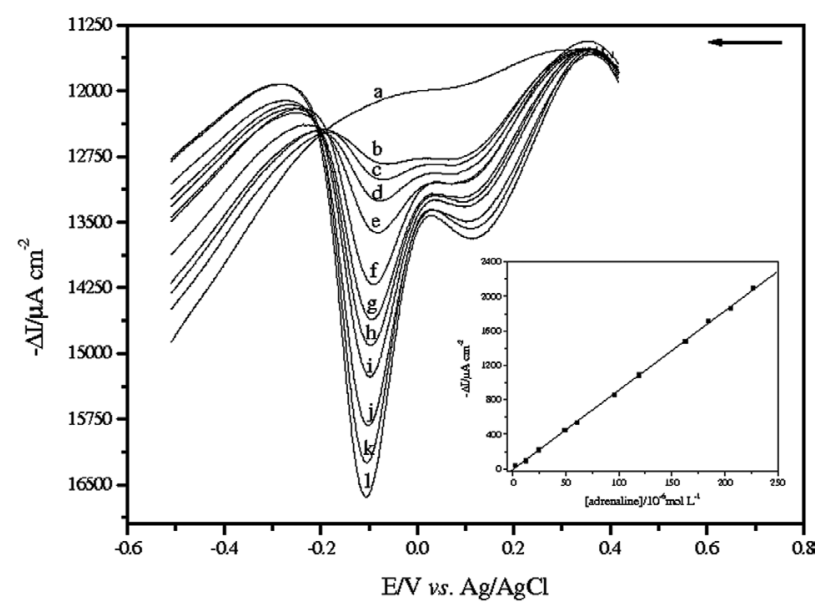

Figure 3. Square wave voltammograms obtained using the BMI-Tf $\mathrm{N}^{-}$ biosensor for (a) blank in $0.1 \mathrm{~mol} \mathrm{~L}^{-1}$ acetate buffer solution ( $\mathrm{pH} 4.0$ ) and adrenaline solutions at the following concentrations: (b) $2.49 \times 10^{-6}$; (c) $1.24 \times 10^{-5}$; (d) $2.48 \times 10^{-5}$; (e) $4.91 \times 10^{-5}$; (f) $6.10 \times 10^{-5}$; (g) $9.61 \times 10^{-5}$; (h) $1.19 \times 10^{-4}$; (i) $1.63 \times 10^{-4}$; (j) $1.85 \times 10^{-4}$; (k) $2.06 \times 10^{-4}$ and (l) $2.27 \times 10^{-4} \mathrm{~mol} \mathrm{~L}^{-1}$ at pulse amplitude $100 \mathrm{mV}$, frequency $10 \mathrm{~Hz}$ and scan increment $4.0 \mathrm{mV}$. Inset: the analytical curve of adrenaline.

or better than, those obtained for the biosensors described in the literature. The good analytical performance for the proposed biosensor can be attributed to the synergism of enzyme laccase and IL BMI·Tf ${ }_{2} \mathrm{~N}$ to the fast electron transfer between adrenaline and biosensor surface.

Repeatability, reproducibility and stability of the $\mathrm{BMI} \cdot \mathrm{Tf}_{2} \mathrm{~N}$ biosensor

The study of the BMI-Tf ${ }_{2} \mathrm{~N}$-biosensor was evaluated by investigating its performance for five parallel determinations of $6.10 \times 10^{-5} \mathrm{~mol} \mathrm{~L}^{-1}$ adrenaline solution

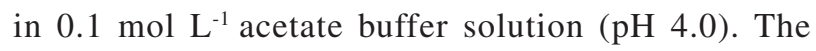
relative standard deviation was calculated as $1.94 \%$. Four biosensors were constructed using the same procedure and were independently used for the adrenaline determination under the conditions described above. All the biosensors revealed an acceptable reproducibility with a relative standard deviation of $2.83 \%$, indicating that the results obtained with the proposed biosensor have a good reproducibility.

The lifetime and stability of the biosensor are very important features, and thus these parameters were also investigated and the response was recorded in a $6.10 \times 10^{-5} \mathrm{~mol} \mathrm{~L}^{-1}$ adrenaline solution ( $\mathrm{pH} 4.0$ ). To examine the long-term stability, the biosensor was tested by repeated measurements without surface renewal over 6 months. When the biosensor was stored at room temperature and measurements taken every 1-2 days in solutions of the same composition, no notable changes were observed in its response, indicating good stability and long lifetime. 
Selectivity, interference, recovery study and determination of the adrenaline in injectable samples

The selectivity of the $\mathrm{BMI} \cdot \mathrm{Tf}_{2} \mathrm{~N}$-biosensor was investigated by voltammetric method and in this experiment were used different compounds, such as, adrenaline, carbidopa, methyldopa, levedopa, sodium chloride, sucrose, lactose, magnesium stearate, poly(ethylene glycol) and starch. The responses were obtained from solutions containing $6.10 \times 10^{-5} \mathrm{~mol} \mathrm{~L}^{-1}$ of the substrates in acetate buffer solution. The sensitivity of the proposed biosensor followed the order: adrenaline > carbidopa $>$ methyldopa $>$ levedopa. No response was observed for sodium chloride, sucrose, lactose, magnesium stearate, poly(ethylene glycol) and starch. Thus, adrenaline was selected for the optimization of the biosensor and application to injectable samples.

In order to evaluate the effect of possible interferents in the determination of adrenaline (compounds mentioned above) were also investigated. Ratios of adrenaline concentration to that each substance was fixed at 1:1. Carbidopa, methyldopa, levedopa caused a positive interference (lower 5.0\%) when present at the same concentration as the analyte and none of the other tested substances interfered in the adrenaline determination with the proposed procedure. In this way, the biosensor was able to determine adrenaline and it was evident that the influence of interfering species tested on the adrenaline response was negligible, indicating a high selectivity of the proposed biosensor.

Recovery experiments of adrenaline were applied using the proposed biosensor, by the standard addition method. Recoveries of 96.3 to $101.6 \%$ of adrenaline, given in Table 2, from injectable samples $(n=3)$ were obtained using the biosensor, the results being considered satisfactory, indicating the absence of matrix effects in these determinations. 8.70, 16.73 and $23.95 \mathrm{mg} \mathrm{L}^{-1}$ adrenaline solutions were added to each sample and the cathodic peak current was registered for the pharmaceutical samples.

The proposed method was validated through the applicability of the BMI-Tf ${ }_{2} \mathrm{~N}$-biosensor in the determination of adrenaline in injectable samples (A and B). The results of the analysis using the biosensor were compared with those obtained using the standard method ${ }^{39}$ (Table 3). T-test (95\%
Table 2. Recoveries of adrenaline $\left(\mathrm{mg} \mathrm{L}^{-1}\right)$ standard solution in injectable samples using the BMI.Tf ${ }_{2} \mathrm{~N}$-biosensor $(n=3)$

\begin{tabular}{lccc}
\hline & \multicolumn{2}{c}{ Adrenaline $/\left(\mathrm{mg} \mathrm{L}^{-1}\right)$} & Recovery $(\%)$ \\
Sample & added & Found & \\
\hline \multirow{2}{*}{ A } & 8.7 & $8.4 \pm 0.1$ & 96.5 \\
& 16.7 & $16.1 \pm 0.2$ & 96.3 \\
& 23.9 & $24.3 \pm 0.1$ & 101.6 \\
B & 8.7 & $8.7 \pm 0.1$ & 100.0 \\
& 16.7 & $16.5 \pm 0.1$ & 98.8 \\
\hline
\end{tabular}

confidence level) performed on these data showed that there was no significant difference between the results obtained using the two methods. It can thus be concluded that the proposed method is suitable for adrenaline determination in these samples.

\section{Determination of the Michaelis-Menten constant}

For the determination of the kinetic parameters of the enzyme in the modified electrodes, the apparent Michaelis-Menten constant have been calculated by fitting the variation of the peak current versus concentration of the adrenaline to the electrochemical Michaelis-Menten equation 1:

$\mathrm{I}=\frac{\mathrm{I}_{\max }[\mathrm{S}]}{\mathrm{K}_{m}^{a p p}}$

where $[\mathrm{S}]$ is the substrate concentration, $\mathrm{I}_{\max }$ is the maximum current and $\mathrm{K}_{m}^{a p p}$ represents the apparent Michaelis-Menten constant. ${ }^{43}$ Figure 4 shows the variation in cathodic peak current versus adrenaline concentration $\left(2.49 \times 10^{-6}\right.$ to $\left.5.18 \times 10^{-4} \mathrm{~mol} \mathrm{~L}^{-1}\right)$ and the Lineweaver-Burk graph is shown in the inset. As can be seen, the current response deviated from linearity and approached a constant value at high adrenaline concentrations. This is attributed to the maximum rate of the enzymatic reaction under adrenaline saturating conditions. The apparent Michaelis-Menten $\left(\mathrm{K}_{m}^{a p p}\right)$ was estimated using the Lineweaver-Burk equation and a value of $\mathrm{K}_{m}^{a p p}=3.25 \mathrm{mmol} \mathrm{L}^{-1}$ was obtained. This kinetic parameter is in agreement with the values reported for a biosensors using laccase from Aspergillus oryzae ${ }^{21}$ and Trametes versicolor.$^{44}$

Table 3. Adrenaline determination in injectable samples using the biosensor and the standard spectrophotometric method

\begin{tabular}{lccccc}
\hline Sample & Label value & Standard method $^{39}$ & BMI.Tf $_{2} \mathrm{~N}-$ biosensor & $\mathrm{R}_{\mathrm{e} 1} /(\%)$ & $\mathrm{R}_{\mathrm{e} 2} /(\%)$ \\
\hline $\mathrm{A}^{*}$ & 1000.0 & $1020.0 \pm 0.1$ & $1005.8 \pm 0.1$ & +0.6 & -1.4 \\
$\mathrm{~B}^{*}$ & 1000.0 & $970.0 \pm 0.2$ & $993.0 \pm 0.1$ & -0.7 & +2.3 \\
\hline
\end{tabular}

$\mathrm{R}_{\mathrm{e} 1}=$ BMI-Tf $f_{2} \mathrm{~N}-$ biosensor $v s$. label value; $\mathrm{R}_{\mathrm{e} 2}=$ BMI.Tf ${ }_{2} \mathrm{~N}-$ biosensor $v$ s. standard method. * $\mathrm{mg} \mathrm{L}^{-1} ; n=3$; confidence level of $95 \%$. 


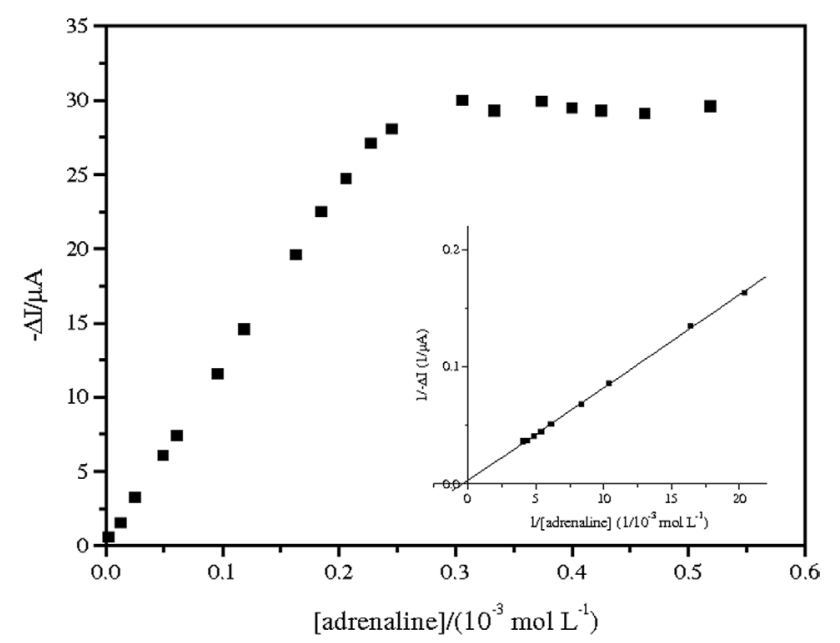

Figure 4. Cathodic current response of the biosensor as a function of adrenaline concentration. Inset: the Lineweaver-Burk graph.

\section{Conclusions}

In this paper, we present novel biosensors based on laccase from Aspergillus oryzae and the ILs, $\mathrm{BMI} \cdot \mathrm{PF}_{6}$ or BMI $\cdot \mathrm{Tf}_{2} \mathrm{~N}$, used as the binders, together with Nujol. The hydrophobic ILs derived from the imidazolium cation associated with the $\mathrm{PF}_{6}^{-}$and $\mathrm{Tf}_{2} \mathrm{~N}^{-}$were used for the determination of adrenaline in injectable samples and were found to be promising candidates for biosensor construction. The BMI-Tf ${ }_{2} \mathrm{~N}$-based biosensor had more favorable analytical features of high sensitivity, linear calibration range, low detection limit, rapid response, good reproducibility and long-term stability. In addition, the low cost, renewability, simplicity and fast construction of the biosensor, using square-wave voltammetry as the analysis method, make it superior to other techniques for adrenaline determination. The results indicate that this catecholamine was successfully determined and the results obtained were satisfactory when compared with the spectrophotometric method.

\section{Acknowledgments}

Financial support from CNPq (Processes 472169/2004-1 and 472541/2006-4), MCT/CNPq/PADCT, NOVOZYMES and also the scholarship granted by CNPq to ACF are gratefully acknowledged.

\section{References}

1. Zeng, Y.; Yang, J.; Wu, K.; Electrochim. Acta 2008, 53, 4615.

2. Amorim, C. G.; Araújo, A. N.; Montenegro, M. C. B. S. M.; Talanta 2007, 72, 1255.

3. Solich, P.; Polydorou, C. K.; Koupparis, M. A.; Efstathiou, C. E.; J. Pharm. Biomed. Anal. 2000, 22, 781.
4. Tzontcheva, A.; Denikova, N.; Clin. Chim. Acta 2000, 297, 217.

5. Sabbioni, C.; Saracino, M. A.; Mandrioli, R.; Pinzauti, S.; Furlanetto, S.; Gerra, G.; Raggi, M. A.; J. Chromatogr., A 2004, 1032, 65 .

6. Sänger-van de Griend, C. E.; Ek, A. G.; Widahl-Näsman, M. E.; Andersson, E. K. M.; J. Pharm. Biomed. Anal. 2006, 41, 77.

7. Du, J.; Shen, L.; Lu, J.; Anal. Chim. Acta 2003, 489, 183.

8. Su, Y.; Wang, J.; Chen, G.; Talanta 2005, 65, 531.

9. Brondani, D.; Dupont, J.; Spinelli, A.; Vieira, I. C.; Sens. Actuators, B 2009, 138, 236.

10. Brondani, D.; Scheeren C. W.; Dupont, J.; Vieira, I. C.; Sens. Actuators, B 2009, 140, 252.

11. Qiao, J. X.; Luo, H. Q.; Li, N. B.; Colloids Surf., B 2008, 62, 31.

12. Beitollahi, H.; Ardakani, M. M.; Ganjipour, B.; Naeimi, H.; Biosens. Bioelectron. 2008, 24, 362.

13. Felix, F. S.; Yamashita, M.; Angnes, L.; Biosens. Bioelectron. 2006, 21, 2283.

14. Grieshaber, D.; Mackenzie, R.; Vöros, J.; Reimhult, E.; Sensors 2008, 8, 1400.

15. Widsten, P.; Kandelbauer, A.; Enzyme Microb. Technol. 2008, 42, 293.

16. Wang, Z.; Xu, Q.; Wang, J. H.; Yang, Q.; Yu, J. H.; Zhao, Y. D.; Microchim. Acta 2009, 165, 387.

17. Franzoi, A. C.; Migowski, P.; Dupont, J.; Vieira, I. C.; Anal. Chim. Acta 2009, 639, 90.

18. Franzoi, A.C.; Dupont, J.; Spinelli, A.; Vieira, I. C.; Talanta 2009, 77, 1322.

19. Fernandes, S. C.; Oliveira, I. R. W. Z.; Fatibello-Filho, O.; Spinelli, A.; Vieira, I. C.; Sens. Actuators, B 2008, 133, 202.

20. Zhang, Y.; Zeng, G. M.; Tang, L.; Huang, D. L.; Jiang, X.Y.; Chen, Y. N.; Biosens. Bioelectron. 2007, 22, 2121.

21. Santhiago, M.; Vieira, I. C.; Sens. Actuators, B 2007, 128, 279.

22. Jarosz-Wilkołazka, A.; Ruzgas, T.; Gorton, L.; Talanta 2005 , 66, 1219.

23. Dupont, J.; J. Braz. Chem. Soc. 2004, 15, 341.

24. Wei, D.; Ivaska, A.; Anal. Chim. Acta 2008, 607, 126.

25. Galiński, M.; Lewandowski, A.; Stepniak, I.; Electrochim. Acta 2006, $51,5567$.

26. Hayashi, K.; Nemoto, Y.; Akuto, K.; Sakurai, Y.; J. Power Sources 2005, 146, 689.

27. Liu, H.; He, P.; Li, Z.; Liu, Y.; Li, J.; Electrochim. Acta 2006, 51, 1925.

28. Suarez, P. A. Z.; Selbach, V. M.; Dullius, J. E. L.; Einloft, S.; Piatnicki, C. M. S.; Azambuja, D. S.; de Souza, R. F.; Dupont, J.; Electrochim. Acta 1997, 42, 2533.

29. Dai, J.; Cheng, J.; Jin, J.; Li, Z.; Kong, J.; Bi, S.; Electrochem. Commun. 2008, 10, 587.

30. Sun, W.; Li, Y.; Gao, H.; Jiao, K.; Microchim. Acta 2009, 165, 313.

31. Li, Y.; Liu, X.; Zeng, X.; Liu, Y.; Liu, X.; Wei, W.; Luo, S.; Microchim. Acta 2009, 165, 393. 
32. Musameh, M. M.; Wang, J.; Anal. Chim. Acta 2008, 606, 45.

33. Sun, W.; Jiang, Q.; Yang, M.; Jiao, K.; Bull. Korean Chem. Soc. 2008, 29, 915.

34. Sun, W.; Li, Y.; Yang, M.; Li, J.; Jiao, K.; Sens. Actuators, B 2008, 133, 387.

35. Ding, C.; Zhang, M.; Zhao, F.; Zhang, S.; Anal. Biochem. 2008, 378, 32.

36. Zhang, Y.; Zheng, J. B.; Electrochim. Acta 2007, 52, 7210.

37. Suarez, P. A. Z.; Dullius, J. E. L.; Einloft, S.; de Souza, R.F.; Dupont, J.; Polyhedron 1996, 15, 1217.

38. Cassol, C. C.; Ebeling, G.; Ferrera, B.; Dupont, J.; Adv. Synth. Catal. 2006, 348, 243.
39. United States Pharmacopeia, The Official Compedia of Standards, Twinbrook Parkway:Rockville, 2007.

40. Liu, Y.; Huang, L.; Dong, S.; Biosens. Bioelectron. 2007, 23, 35.

41. Liu, Y.; Dong, S.; Electrochem. Commun. 2007, 9, 1423.

42. Liu, Y.; Dong, S.; Biosens. Bioelectron. 2007, 23, 593.

43. Haghighi, B.; Gorton, L.; Ruzgas, T.; Jönsson, L. J.; Anal. Chim. Acta 2003, 487, 3.

44. Freire, R. S.; Durán N.; Kubota, L. T.; Talanta 2001, 54, 681.

Received: April 8, 2009

Web Release Date: March 29, 2010 